Eskişehir Osmangazi Üniversitesi iiBF Dergisi

Ağustos 2019, C. 14, S. 2, 491 - 510.

Başvuru :01.02.2019

Kabul : : 26.07.2019

\title{
Kripto Para Birimi Piyasalarında Etkinliğin Uzun Hafıza ve Değişen Varyans Özelliklerinin Testi Yoluyla Analizi ${ }^{1}$
}

Tuna Can Güleç²

Hüseyin Aktaş3

Kripto Para Birimi Piyasalarında Etkinliğin Uzun Hafıza ve Değişen Varyans Özelliklerinin Testi Yoluyla Analizi

Öz

Çalışmanın amacı, kripto para birimi piyasalarındaki fiyat hareketlerini etkinlik açısından değerlendirerek piyasanın geleceğine dair kritik noktalara ışık tutmaktır. Bu kapsamda piyasa etkinliğine dair uzun hafıza ve değişen varyans özellikleri test edilmiştir. Piyasa derinliği ve volatilite yapısı arasındaki ilişki, 8 kripto para birimi için asimetrik GARCH modelleri kullanılarak incelenmiştir. Analiz bulguları, kripto para piyasalarında uzun hafıza özelliğinin varlığını ortaya koymaktadır. Buna ek olarak, elde edilen bulgulara göre, tüm kripto para birimleri için işlem hacmi arttıkça volatilitede azalma gözlemlenmektedir. Dolayısıyla, piyasa etkinliğinin tüm kripto para birimleri için piyasa derinliğiyle birlikte arttığı sonucuna ulaşımaktadır.

Bu çalışma, güncel finans literatürünün en tartışmalı konularından birisi olan kripto para piyasalarının geleceğine dair sinyallere işaret etme aracılığıyla literatüre katkı sağlamaktadır.

Anahtar Kelimeler: Finans, Kripto para, Fintek, GARCH
Testing the Market Efficiency in Crypto Currency Markets Using Long-Memory and Heteroscedasticity Tests

Abstract

The purpose of this study is to shed light on the critical points of the future of the crypto currency market by evaluating the price movements and market efficiency. In this context, efficiency structure of the market has been tested for long-memory and heteroscedasticity characteristics. The relationship between market depth and volatility structure has been tested for 8 crypto currencies using asymmetrical GARCH models. Results of the analysis indicate presence of long-memory characteristics. Additionally, that as market volume increases so does the efficiency of the market. Therefore, it is concluded that the market efficiency increases with the market depth for all tested crypto currencies.

This study contributes to the literature by pointing out the signals about the future of the crypto currency markets, which is one of the most controversial issues in the current finance literature.

Keywords: Finance, Cryptocurrency, Fintech, GARCH

\section{Giriş}

Kripto para birimleri piyasası günümüzde, pazara yeni gelen bilgiye en hızlı ve güçlü tepki veren piyasalar arasındadır. Elbette tüm fiyat değişimleri yeni bilgilerin sonucu değildir, spekülatif amaçlı işlemler, manipülatif amaçlı işlemler veya rasyonel süreçlerle açıklanması mümkün olmayan birçok işlem kripto para piyasalarını etkilemektedir. Tüm bu etkenlerin toplu olarak piyasada yarattıkları dalgalanmalar piyasa volatilitesini oluşturmaktadır. Artan volatilite, piyasada risk algısını arttırdığından dolayı, belirli bir getiri seviyesi için kabul edilebilir olan risk seviyesi, yeni durumda alternatif yatırım kararlarının gerisinde kalabilir. Bu nedenle getirisine oranla, yüksek volatilite içeren piyasalar çoğu yatırımcı tarafından tercih edilmez.

Kripto para piyasaları, yeni ortaya çıkan piyasalar olmalarının da etkisiyle yüksek volatilite içermektedir. Teorik olarak, piyasadaki volatilitenin tamamı, piyasaya yeni gelen bilgilerin so-

\footnotetext{
${ }^{1}$ Bu çalışma Manisa Celal Bayar Üniversitesi Sosyal Bilimler Enstitüsü Muhasebe ve Finans Anabilim Dalı'nda Prof. Dr. Hüseyin Aktaş danışmanlığında Tuna Can Güleç tarafından “Blockchain Tabanlı Kripto Para Birimlerinin Mevcut Durumuna Dair Finansal Analizler ve Geleceği” ismiyle tamamlanarak 28.09.2018 tarihinde savunulan doktora tezinden türetilmiştir.

${ }^{2}$ Arş. Gör. Dr., Manisa Celal Bayar Üniversitesi iiBF, İşletme Bölümü. tunacan.gulec@cbu.edu.tr, yazar ORCID bilgisi: https://orcid.org/0000-0003-2551-6460.

3 Prof. Dr., Manisa Celal Bayar Üniversitesi iỉB, İşletme Bölümü. huseyin.aktas@cbu.edu.tr, yazar ORCID bilgisi: https://orcid.org/0000-0002-0580-4644.
} 
nucu olarak ortaya çıkıyor ise piyasanın etkin olduğundan bahsetmek mümkündür. Bu kapsamda gerçekleşen volatilite, piyasaların doğal yapısından kaynaklıdır. Öte yandan kripto para piyasalarındaki volatilitenin büyük kısmı bu doğal yapıdan kaynaklı olarak ortaya çıkmamaktadır. Manipülasyonların yarattığı volatiliteye ve etkilerine işaret eden çok sayıda çalışma literatürde mevcuttur (Balcilar vd., 2017: 74; Cheah ve Fry, 2015: 32; Gandal ve Halaburda, 2016: 16).

Kripto para piyasalarının rasyonel yatırımcı tarafından yatırım yapılabilir seviyeye gelebilmesi için, günümüzde içerdiği yüksek volatilite seviyesinin azalması gerekmektedir. Zira, günümüzde kripto para birimleri piyasasının içerdiği volatilite seviyelerine sahip hiçbir varlık veya para biriminin uluslararası bir değer saklama aracı veya değer değişim birimi olması beklenemez. Çalışma kapsamında gerçekleştirilen analizler, kripto para piyasalarının volatilite düzeylerini etkin piyasa hipotezinin temel iddiası olan "Fiyatlar piyasadaki tüm bilgiyi yansıtır." varsayımı ile sınamayı amaçlamaktadır.

Bu kapsamda geçmiş fiyat serilerinin güncel fiyatların üzerinde kalıcı etkisinin olup olmadığı uzun hafıza testleriyle sınanmıştır. Bunu takiben piyasa derinliği ve volatilite arasındaki ilişkiyi ortaya koyabilmek için 8 farklı kripto para birimi (Bitcoin(BTC), Ethereum(ETH), Litecoin(LTC), Ripple(XRP), Bitcoin Cash(BCH), Cardano(ADA), IOTA(MIOTA) ve NEO(NEO) ) üzerinde asimetrik GARCH modelleri vasıtasıyla etkinlik analizi gerçekleştirilmiştir. Araştırmanın sınadığı hipotez, piyasa derinliği arttıkça volatilitenin azalacağıdır. Bu yönde bir bulgu, piyasanın etkin olduğuna dair bir işaret olarak yorumlanabilir.

\section{Kavramsal Çerçeve}

Illk kripto para birimi olan Bitcoin 'i literatüre kazandıran bilimsel çalışma, uçtan uca merkezsiz iletişim ve kriptografik şifreleme sistemlerinin bütünleşik kullanımı vasıtasıyla blok zinciri sistem yapısının temellerini atmıştır (Nakamoto, 2008: 1). Her bir kripto para birimlerine dair teknik literatürün kökeni, "White Paper" olarak adlandırılan ve o kripto para birimine özgü yayınlanan bilimsel tanıtım belgelerine dayanmaktadır. Kripto para birimlerinin büyük çoğunluğunun teorik altyapısını bu tanıtım belgeleri oluşturmaktadır. Öte yandan kripto para birimlerinin prototip modeli olarak ortaya çıkan Bitcoin yapısal olarak, ölçeklenememe ve aşırı uzun işlem süreleri gibi kalıcı sorunlara sahiptir. Bu sorunların ortadan kaldırılması amacıyla, yeni nesil kripto para birimleri, kendi tanıtım belgelerini yayınlayarak piyasaya giriş yapmışlardır. Bu tanıı ı belgelerinde, ilgili kripto para birimine ait teknolojik ve ekonomik altyapılar teknik olarak açıklanmakta ve var olan sistemler üzerindeki üstünlükleri belirtilmektedir.

Kripto para birimleri, hiçbir merkezi tekel tarafından müdahale edilemeyen ve tüm kullanıcıların ortak demokratik tercihleri doğrultusunda evrim geçirmek üzere tasarlanmış finansal yapılardır. Bu yapının ilk ve aynı zamanda kusurlu bir örneği olan Bitcoin, günümüzde çok ciddi yapısal sorunlara maruz kalmaktadır. Günlerle ifade edilen işlem süreleri, küçük ülkelerin tüketimiyle yarışan gereksiz enerji sarfiyatı ve ölçeklenememe sorunu, Bitcoin 'i mevcut finansal sisteme alternatif olmaktan uzaklaştırmaktadır. Öte yandan yaygın algının aksine Bitcoin, ilk ve tek kripto para birimi olmak üzere tasarlanmamıştır. Dahası, Bitcoin 'in tanıtım belgesinde ortaya koyduğu blok zincir algoritmasıyla, gelecek kripto para birimlerinin oluşumu için kullanılabilecek bir altyapı oluşturmuştur. Blok zincir algoritmasının değiştirilmiş ve hatta geliştirilmiş birçok sürümü kullanılarak oluşturulan binlerce kripto para birimi, günümüz kripto piyasalarında işlem görmektedir. 
Teknolojik ve ekonomik tasarımları itibariyle üç nesil altında kategorize edilebilen kripto paralar, piyasa katılımcılarının teknik ve ekonomik olarak daha başarılı kripto para birimlerini tercih ederek onlara geçiş yapacağı varsayımıyla oluşturulmuş bir doğal seleksiyon mekanizmasına sahiptir. Günümüzde Bitcoin 'in kusurlarının büyük çoğunluğundan arınmış üçüncü nesil kripto para birimleri bulunmaktadır. Öte yandan, aradan geçen 10 yıldan uzun süreye ve önerilen yüzlerce yeni sisteme rağmen, günümüzde piyasa katılımcılarının büyük çoğunluğu, güncelliğini yitirmiş kripto para sistemlerinden güncel sistemlere taşınmayı reddetmektedir. 2019 yılı ilk çeyreği itibariyle, piyasa değeri bakımından en büyük ilk on kripto para birimi içerisinde, bahsi geçen yapısal sorunları çözüme kavuşturmuş tek bir kripto para birimi yoktur. Kripto para birimleri teknik ve ekonomik tasarım olarak gelişmektedir, fakat yatırımcılar ve kullanıcılar, bu gelişmiş kripto para birimlerine geçiş yapmamaktadır. Diğer bir deyişle, kripto para sistemi için öngörülen doğal seleksiyon sistemi çalışmamaktadır. Bu durum, literatürde büyük çoğunlukla piyasa dinamiklerine odaklanılmasına neden olmuştur. Bu hususta piyasa katılımcılarının davranışlarını inceleme amacıyla gerçekleştirilen ulusal ve uluslararası çalışmalar mevcuttur.

Kripto para birimleri arasındaki rekabeti, piyasa dinamikleri üzerinden değerlendiren önemli bir çalışma (Gandal ve Halaburda, 2014: 1), farklı kripto paralar arasındaki çapraz kur oranlarını ve kripto borsalar arasındaki fiyat farklılıklarını ele almıştır. Araştırma bulguları kripto para piyasasında uzun vadede, tüm piyasaya hakim tek bir kripto paranın kalacağına işaret etmektedir. Öte yandan Bitcoin 'in Amerikan Doları karşısındaki değer artışını takip eden düşüş sürecinin, araştırma bulgularıyla çeliştiğine vurgu yapılmaktadır.

Uluslararası literatürde Bitcoin haricindeki kripto para birimlerinin GARCH veya türevi yöntemlerle modellenmesi konusunda büyük bir boşluk bulunmaktadır. Bu alandaki kapsamlı bir çalışma, en popüler 7 kripto para birimi için 12 farklı GARCH modelini test etmiş ve önceden belirlenmiş kriterlere göre en uyumlu modelleri raporlamıştır (Chu vd., 2017: 17). Araştırma sonuçlarına göre yüksek hacme sahip kripto para birimlerinin, volatilite serilerinin modelleme süreçlerinde, IGARCH ve GJRGARCH yöntemlerinin kullanımı en uygun sonuçları vermektedir. Bu öneriyi destekleyen bir başka çalışma, sonsuz hafızaya sahip koşullu varyans serilerinin kullanıldığı IGARCH modelinin, çok sayıda yapısal kırılma barındıran piyasalarda kullanıma uygun olduğu yönünde bulgular elde etmiştir (Caporale ve Spagnolo, 2003: 72). Nisan 2013 ile Mayıs 2017 tarihleri arasında arz edilen 1469 kripto para birimine ait piyasa verilerini kullanarak, kripto para birimleri piyasasının gelişim sürecini yorumlayan bir başka çalışma, kripto para birimleri fiyat hareketlerinin üstel bir desen sergilediği bulgusunu elde etmiştir (El Bahrawy, 2017: 170623). Bunula birlikte, üstel fiyat hareketlerine rağmen piyasadaki, pazar payı dağılımı ve dönüşüm oranı gibi değişkenlerin tutarlı hareket ettiği sonucuna ulaşılmıştır. Bu bulgular ışığında, kripto para piyasasını ekolojik bir bakış açısıyla yorumlayan çalışma, ve kripto para piyasası gelişim süreci ile canlıların evrim süreci arasında yüksek oranda benzerlik olduğu yorumuna ulaşmıştır.

Kripto para piyasalarında spekülatif balonların varlığı üzerinde gerçekleştirilen ulusal bir çaIışmada (Ceylan vd., 2018: 209), Ethereum ve Bitcoin kripto para birimlerinde çok sayıda küçük baloncuk tespit edilmiştir. Bu sonuçlarla örtüşecek şekilde, bir başka ulusal çalışmada, (Dirican ve Canoz, 2017: 382) ARDL sınır testi yöntemiyle Bitcoin fiyatları ve dünya borsaları arasındaki ilişki incelenmiştir ve belirli borsalarda eş bütünleşme etkisi tespit edilmiştir.

Kripto para piyasalarında yatırımcı davranışlarını modellemeyi hedefleyen deneysel çalışmalar, piyasaya aktif olarak müdahalelerde bulunmak suretiyle elde ettikleri verileri raporla- 
mışlardır. Bu tip bir deneysel çalışma, piyasada aktif olarak işlem yapan botlar aracılığıyla piyasaya müdahale ederek, katılımcıların tepkilerini ölçümlemiştir (Krafft vd., 2018: 605). İlgili çaışma kapsamında elde edilen bulgular, botların kısa vadede piyasa yapıcı özelliğe sahipken, uzun vadede etkisi olmadığı yönündedir. Ampirik çalışmaların yanı sıra, yapay piyasa ortamı ve katılımcıları kullanarak simülasyon yöntemiyle piyasayı modelleyen çalışmalar da literatürde yer almaktadır (Cocco vd., 2017: 351). Öte yandan piyasa yapısına dair gerçekleştirilen tahminler, piyasa dinamiklerinin değişken olması sebebiyle tutarsız kalmaktadır.

Etkin piyasa hipotezini ortaya atan Eugene F. Fama bir piyasanın mutlak düzeyde kuvvetli etkin olup olmayacağının kesin olarak bilinemeyeceğini fakat çeşitli makroekonomik değişkenlere ve dışsal etkilere tepki olarak gösterdiği fiyat değişimlerinden 3 temel form altında sınıflandırılabileceğini belirtmiştir (Fama, 1970: 383). Zayıf formdaki piyasalarda Fama'nın tabiriyle “Piyasayı yenmek", terminolojik tabiriyle ise uzun vadede ortalama getirinin üzerinde kazanç elde etmek mümkün değildir. Bunun sebebi geçmiş fiyatların gelecek fiyatlar üzerinde etkisinin olmamasıdır. Orta etkin (Yarı-Güçlü) piyasalarda zayıf form etkinlik düzeyi koşuluna ek olarak, halka açık bilgileri kullanarak teknik analizlerle ortalamanın üstünde getiri elde etmek mümkün değildir çünkü tüm bilgi zaten fiyatlanmıştır. Güçlü etkin piyasalarda ise içten bilenlerin ticareti (insider trading) dahi yapılsa piyasayı yenmek mümkün değildir. Çünkü ya içten bilmek mümkün değildir ya da içsel bilgiler dahi fiyatlanmıştır. Bu senaryolar dâhilinde ortalama üstü getiri elde eden kişi standart sapmalar dahilindedir ve ticaret yapmaya devam ettikçe ortalamalar kanununa göre piyasa ortalama getirisine yaklaşacaktır (Fama, 1965b: 34).

Fama'nın çalışmasında belirttiği ortalamalar kanununun etkin olabilmesi için piyasanın belirli bir hacme veya derinliğe sahip olması gerekmektedir (Fama 1965a: 404). Zaman serisi yapısındaki serilerde uzun hafıza özelliği kavramı piyasa etkinliği ölçebilme açısından tam anlamıyla biçilmiş kaftandır. Genel anlamda, rassal bir zaman serisinin otokorelasyon fonksiyonu integrali alınamayacak şekilde çıkarsa, serinin uzun hafıza özelliği olduğundan söz edebiliriz. Bu durum otokorelasyon fonksiyonunun asimptotik olarak azaldığı durumlarda ortaya çıkabilmektedir (Granger ve Joyeux, 1980: 15). Granger bu senaryonun finansal zaman serilerinde geçmiş şokların etkilerinin sonraki dönemlerde de kalıcılık gösterdiğine dair bir işaret olabileceğini belirtmiştir.

Uzun hafıza, finansal zaman serilerinin modellenmesinde dikkate alınması gereken unsurlardan biridir ve mihenk taşı kabul edilen birçok çalışma uzun hafıza özelliğinden adeta "finansal zaman serilerinin kalıtsal hastalığı" olarak bahsetmektedir (Granger ve Joyeux, 1980: 15; Hosking, 1981: 165). Uzun hafıza, aşırı volatilitenin neden olduğu zarar ve kayıpları minimize etmekte ve uygun varlık bölüşümüne imkan sağlamaktadır. Bu durum yatırımcıların gelecek hisse senedi fiyatlarına ilişkin beklentilerini ve dolayısıyla, piyasa etkinliğini etkilemektedir. Burton, piyasanın uzun hafıza özelliği sergilediğinde, uzun dönem önceki geçmiş olayların bugünkü fiyatları etkileyeceğini ifade etmiştir (Burton, 1987: 21). Yatırımcılar ve portföy yöneticileri, uzun hafıza ve yapısal kırılmanın gelecekteki volatiliteyi nasıl etkilediğini dikkate alarak gelecekte uğrayacakları zararları önlemeye çalışmaktadırlar. Uzun hafıza ve yapısal kırılma özelliklerinin finansal zaman serileri kullanılarak gerçekleştirilen analizlerde dikkate alınması, ekonomik ve istatistiksel anlamlılığı arttırmaktadır (Mensi vd., 2015: 340).

Literatürde çok sayıda çalışma uzun hafıza özelliğini çeşitli finansal veri setleri üzerinde test etmiştir. Uzun hafıza özelliği, gelişmekte olan ülke borsalarında gelişmiş ülke borsalarına oranla daha belirgin bir şekilde gözlemlenmiştir (Cheung ve Lai, 1995: 597; Lahmiri, 2015: 130). Bu durum aynı zamanda bir piyasada uzun hafıza özelliğinin aranabilmesi için, piyasanın belirli bir 
süredir işliyor olması ve belirli bir işlem hacmine erişmiş olması gerektiği durumuna da işaret etmiştir. Finansal volatilite modellemesi çalışmalarının babası olarak görülen ARCH süreçleri 1982 yılında modellenmiş olan Otoregresif koşullu değişen varyans modellerinin türevleridir (Engle, 1982: 987). GARCH süreçlerini kullanarak volatilite modellenmesinde uzun hafıza özelliğinin varlığına dikkat çeken çalışmalar (Barkoulas vd., 2000: 177; Ding vd., 1993: 83) uzun hafıza özellikleri barındıran serilere özel tasarlanmış GARCH süreçlerinin doğumuna öncülük etmiştir.

Finansal piyasalarda volatilitenin modellenmesinde GARCH ve EGARCH modellerinin kısmi olarak entegrasyonu (Kısmi Bütünleşik (FI)) ve Monte Carlo simülasyonları vasıtasıyla güvenilirliğinin güçlendirilmesi ile FIEGARCH modeli ilk kez 1996 da Amerikan hisse senedi piyasaları için kullanılmıştır. Model piyasadaki fraksiyonel uzun hafıza özelliğini dikkate alacak şekilde kurgulanmıştır (Bollerslev ve Mikkelsen, 1996: 151). Aynı yıl içinde bu modeli Alman Markı ve Amerikan Doları kurları için kullanan bir başka çalışma (Baillie vd., 1996: 3), piyasa yapısındaki farklılıktan kaynaklı olarak FIEGARCH modelinin BBM versiyonunu kullanmıştır. Yaklaşık 2 yıl sonra Japon Yeni ve Amerikan Doları kurlarının volatilitesini modelleme amacıyla bu model, FIAPARCH adı altında yeniden yapılandırılmıştır (Tse, 1998: 49).

\section{Araştırmada Kullanılan Yöntemler}

Araştırmada kullanılan serilerde uzun hafıza etkisi gözlemlendiğinden, uzun hafıza etkisini dikkate alan kısmi bütünleşik volatilite modelleme yöntemlerinin kullanılmasına karar verilmiştir. Bir seri uzun hafıza karakteristiği sergiliyorsa, bunu dikkate almadan yapılacak analizler sapmalı sonuçlar verecektir (Turgutlu, 2004: 55). Kısa hafıza, kovaryans durağan bir serinin otokorelasyon fonksiyonunun değerlerinin üstel bir hızla küçüldüğünü, uzun hafıza ise kovaryans durağan bir serinin otokorelasyon fonksiyonunun değerlerinin hiperbolik olarak yavaş bir şekilde küçüldüğünü ifade etmektedir.

Koşullu ortalamanın uzun hafıza özelliklerini test etmek amacıyla kullanılan araçlardan birisi, otoregresif friksiyonel bütünleşik hareketli ortalama (ARFIMA) modelidir. Bu model, koşullu ortalamadaki friksiyonel olarak bütünleşik süreci, I(d) ile göstermektedir. ARFIMA $(p, d, q)$ modeli aşağıdaki gibidir:

$$
\begin{gathered}
\Psi(L)(1-L)^{d}\left(y_{t}-\mu\right)=\theta(L) \varepsilon_{t} \\
\varepsilon_{t}=z_{t} \sigma_{t}
\end{gathered}
$$

$\varepsilon_{t}$, varyansı $\sigma_{t}^{2 \prime}$ dir ve bağımsız ve özdeş dağılmıştır. L gecikme sürecini temsil etmektedir. $\Psi(L)=1-\sum_{i=1}^{n} \Psi_{i} L^{i}$ ve $\theta(L)=1-\sum_{j=1}^{s} \theta_{j} L^{j}$ ifadelerinde d parametresi, ortalamada uzun hafıza özelliğini temsil eder.

Hosking, $y_{t}$ sürecinin aşağıdaki davranışları sergilediğini varsaymaktadır (Hosking, 1981: 165):

a) Eğer $-0.5<\mathrm{d}<0,5$ ise, durağandır ve geçerlidir.

b) Eğer $\mathrm{d}=0$ ise, durağandır ve kısa hafızaya sahiptir.

c) Eğer $\mathrm{d}=1$ ise birim kök sürecine sahiptir.

d) Eğer $0<\mathrm{d}<0.5$ ise uzun hafızaya sahiptir ve gözlemler arasında pozitif bağımlılık vardır.

e) Eğer $-0.5<\mathrm{d}<0$ ise, gözlemler arasında negatif bağımlılık vardır.

ARFIMA sürecinin otokorelasyon fonksiyonunda yer alan değerler hiperbolik olarak azalırken, ARMA modelinde üssel olarak azalmaktadır. Bu nedenle ARFIMA modelinde otokorelasyon 
değerleri daha yavaş azalmaktadır (Cheung ve Lai, 1993: 313). Uzun hafızaya sahip olan eşbütünleşme ilişkisinden sapmalar söz konusu olduğunda, şokların etkisi ARMA sürecine sahip ve kovaryans durağan serilerin otokorelasyon fonksiyonlarında ortaya çıkan üssel azalmadan daha yavaş bir şekilde azalmaktadır (Bollerslev vd., 1994: 2959).

Uzun hafıza süreci, koşullu oynaklık modellerine genişletilebilmektedir. Bu modellerden biri olan FIGARCH modeli Baillie tarafından geliştirilmiştir (Baillie vd., 1996: 3). FIGARCH (1,d,1) modeli aşağıdaki gibi ifade edilebilir:

$$
\sigma_{t}^{2}=\omega[1-\beta(L)]^{-1}+\left[1-(\beta(L)]^{-1} \varphi(L)(1-L)^{d} \varepsilon_{t}^{2}\right.
$$

Burada $\omega, \beta, \varphi$, ve d sırasıyla sabit terimi, GARCH terimi, ARCH teimi ve uzun hafıza parametresini göstermektedir. Friksiyonel fark operatörü $(1-L)^{d}$ koşullu volatilitedeki uzun hafıza özelliğini ölçmektedir. $0<d<1$ olduğunda, zaman serisi volatilitede uzun hafıza süreci göstermektedir.

Bu yöntemler içerisinden hisse senedi fiyatlamaya yönelik olan FIEGARCH modeli ve döviz kuru fiyatlamaya yönelik olan FIEGARCH BBM yöntemleri ele alınmıştır. Model uyumu Akaike ve Schwarz bilgi kriterine ve GARCH model parametrelerine göre FIEGARCH BBM modelinde anlamlı bir şekilde gerçekleşmiştir.

FIEGARCH $(p, d, q)$ modeli aşağıdaki gibidir:

$$
\ln \left(\sigma_{t}^{2}\right)=\omega+\phi\left(L^{-1}\right)(1-L)^{-d}[1+\alpha(L)] g\left(z_{t-1}\right)
$$

Model EGARCH sürecinde otoregresif bileşenlerin aşağıdaki gibi çarpanlara ayırılmasıyla uzun hafızaya uygun hale getirilmiştir:

$$
[1-\beta(L)]=\phi(L)(1-L)^{d}
$$

(Bu denklemde tüm birim köklerin $\phi(z)=0$ çevresinde dağıldığı varsayılmaktadır.)

\section{Kripto Para Piyasalarında Volatilite Yapısı ve Hacim Illişkisi Analizi}

Tam etkin olarak nitelendirilen bir finansal piyasada geçmiş şokların etkilerinin kalıcı olmaması ve yatırımcıların aynı güçteki pozitif ve negatif şoklara eşit büyüklükte tepkiler vermesi beklenir. Bununla birlikte teorik olarak, etkin bir piyasada manipülasyon gerçekleştirmek mümkün değildir. Etkin olmayan piyasalarda ise şokların volatiliteyi arttırıcı etki göstermesi beklenmektedir. Buradan hareketle olgunlaşmamış bir finansal piyasanın, işlem hacmi arttıkça volatilitesinin azalması ve bununla birlikte uzun hafıza ve asimetrik etki gibi özelliklerden uzaklaşması beklenmektedir. Bu durumda söz konusu piyasanın etkinlik seviyesinin yükseldiğini söylemek mümkündür.

\subsection{Veri Seti}

Araştırmada kripto para birimlerine ait zaman serilerinde uzun hafıza özelliğini test etmek amacıyla 28.04.2013 ile 4.02.2018 tarihleri arasına karşılık gelen günlük frekansta gözlemler kullanılmıştır. Piyasa kapanmadığı için bir kapanış fiyatı mevcut değildir. Volatiliteyi azaltıcı bir etki yaratacağı görüşünden hareketle, günlük ortalama fiyat kullanımı yaklaşımı benimsenmemiştir. Dolayısıyla kapanış fiyatı olarak Greenwich (GMT +0) saatiyle 00:00'daki fiyatlar kullanılmıştır. Bu saat, Türkiye saatiyle yatırımcıların aktif işlem yaptıkları düşünülen bir saate denk gelmemesine karşın dünya piyasalarının \%67 sinden fazlası için aktif işlem saati olarak düşülen saatler içerisindedir. Aynı veri toplama yöntemi piyasa hacmi serileri için de uygulanmıştır, 00:00 - 23:59 saatleri arası 24 saatlik süre içerisindeki toplam işlem hacmi dikkate alınmıştır. 
Analiz edilen 8 kripto para birimine ait fiyat ve hacim verileri kullanılarak, toplam 16 seri elde edilmiştir. Bu seriler logaritmik farkları alınarak analizlerde kullanılmıştır. Seriler aralarındaki büyük gözlem sayısı farklarından dolayı 2 gruba ayrılmıştır. 4 adet yüksek gözlem sayısına sahip kripto para birimi BITCOIN, LITECOIN, ETHEREUM ve RIPPLE olgun piyasalar olarak bir arada raporlanmış ve uzun hafıza özelliklerini dikkate alan modellerle analiz edilmişlerdir. Düşük gözlem sayısına sahip NEO, CARDANO, BITCOIN CASH ve IOTA ise GARCH yöntemiyle modellenmiş ve ayrı analiz edilmişlerdir.

Veri setinin tanımlayıcı istatistikleri aşağıdaki gibidir:

\section{Tablo 1: Olgun Piyasalara dair Tanımlayıcı İstatistikler}

\begin{tabular}{|c|c|c|c|c|}
\hline & $\begin{array}{c}\Delta \mathrm{L} \text { BTC } \\
\text { KAPANIŞ }\end{array}$ & $\begin{array}{l}\Delta \text { L BTC } \\
\text { HACIM }\end{array}$ & $\begin{array}{c}\Delta \mathrm{L} \text { LTC } \\
\text { KAPANIŞ }\end{array}$ & $\begin{array}{c}\Delta \text { L LTC } \\
\text { HACIM }\end{array}$ \\
\hline Ortalama & 0.0024 & -0.0015 & 0.0005 & -0.0008 \\
\hline Medyan & 0.0020 & 0.0077 & 0.0000 & 0.0210 \\
\hline Maksimum & 0.3575 & 0.7224 & 0.2216 & 0.7966 \\
\hline Minimum & -0.2662 & -1.0821 & -0.2232 & -1.3532 \\
\hline Std. Sapma & 0.0446 & 0.1835 & 0.0263 & 0.2208 \\
\hline Çarpıklık & -0.1805 & -0.4617 & 0.5574 & -0.7015 \\
\hline Basıklık & 11.3906 & 4.8062 & 16.9925 & 5.1332 \\
\hline Jarque-Bera & $5122.36^{* * *}$ & $257.19^{* * *}$ & $12232.47^{* * *}$ & $404.70 * * *$ \\
\hline ADF & $-41.25^{* * *}$ & $-25.36^{* * *}$ & $-38.42 * * *$ & $-24.61 * * *$ \\
\hline PP & $-41.22^{* * *}$ & $-77.11^{* * *}$ & $-38.44 * * *$ & $-73.83 * * *$ \\
\hline KPSS & 0.23 & 0.10 & 1.05 & 0.31 \\
\hline$Q(30)$ & $80.040^{* * *}$ & $353.37^{* * *}$ & $58.233 * * *$ & $131.17^{* * *}$ \\
\hline$Q^{2}(30)$ & $762.29^{* * *}$ & $382.36^{* * *}$ & $140.81 * * *$ & $95.059 * * *$ \\
\hline ARCH-LM & $186.97^{* * *}$ & $33.11^{* * *}$ & $33.21 * * *$ & $6.00 * * *$ \\
\hline \multirow[t]{2}{*}{ Gözlem Sayısı } & 1743 & 1500 & 1500 & 1500 \\
\hline & $\begin{array}{c}\Delta \text { L ETH } \\
\text { KAPANIŞ }\end{array}$ & $\begin{array}{l}\Delta \text { L ETH } \\
\text { HACIM }\end{array}$ & $\begin{array}{c}\Delta \text { L XRP } \\
\text { KAPANIŞ }\end{array}$ & $\begin{array}{l}\Delta \text { L XRP } \\
\text { HACIM }\end{array}$ \\
\hline Ortalama & 0.0032 & -0.0037 & 0.001427 & -0.0030 \\
\hline Medyan & -0.0002 & 0.0110 & -0.0010 & 0.013959 \\
\hline Maksimum & 0.1315 & 0.7016 & 0.446175 & 1.040352 \\
\hline Minimum & -0.1370 & -0.7742 & -0.2676 & -1.2892 \\
\hline Std. Sapma & 0.0305 & 0.2296 & 0.035058 & 0.277148 \\
\hline Çarpıklık & 0.2871 & -0.2966 & 2.059165 & -0.4025 \\
\hline Basıklık & 6.1700 & 3.0961 & 30.33096 & 4.010351 \\
\hline Jarque-Bera & $389.63 * * *$ & $13.55^{* * *}$ & $52043.54^{* * *}$ & $113.68^{* * *}$ \\
\hline ADF & $-28.58 * * *$ & $-17.67^{* * *}$ & $-38.25^{* * *}$ & $-26.36^{* * *}$ \\
\hline PP & $-28.61 * * *$ & $-61.83 * * *$ & $-39.00^{* * *}$ & $-71.59^{* * *}$ \\
\hline KPSS & 0.11 & 0.07 & 0.22 & 0.10 \\
\hline$Q(30)$ & 40.116 & $128.15^{* * *}$ & $57.169^{* * *}$ & $313.79^{* * *}$ \\
\hline$Q^{2}(30)$ & $168.35 * * *$ & $95.155^{* * *}$ & $248.57^{* * *}$ & $43.151^{* *}$ \\
\hline ARCH-LM & $60.24^{* * *}$ & 2.90* & $133.61^{* * *}$ & $2.27^{*}$ \\
\hline Gözlem Sayısı & 901 & 901 & 1635 & 1635 \\
\hline
\end{tabular}

Not: $*, * * * *$ sırasıyla $\% 10, \% 5$ ve $\% 1$ önem düzeylerinde anlamlılıkları ifade etmektedir. $\Delta$ değişkenin birinci farkının alındığını göstermektedir.

Tablo 1'de Olgun kripto para birimlerine ilişkin günlük kapanış fiyatları ve işlem hacmi serilerinin logaritmik birinci farklarına dair tanımlayıcı istatistikler yer almaktadır. Bunlarla birlikte birim kök testlerine de yer verilmiştir. Bitcoin kripto para birimine ilişkin getiri serisinin logaritmik birinci farklarını ifade eden $\triangle \mathrm{L}$ BTC KAPANIŞ ve hacminin logaritmik birinci farklarını ifade eden $\triangle \mathrm{L}$ BTC HACIM değişkenlerine ait çarpıklık, basıklık ve Jarque-Bera değerleri incelendiğinde, her iki değişkenin de normal dağılım sergilemediği, kalın kuyruk özelliğine sahip olduğu 
ve leptokurtik dağılım özelliği gösterdiğini gözlemlenmektedir. Aynı zamanda her iki değişken de sağa çarpıktır.

Birim kök testleri incelendiğinde, ADF ve PP test sonuçları istatistiksel olarak anlamlı, KPSS sonuçları ise istatistiksel olarak anlamsız raporlanmıştır. Bu sonuçlar hem $\triangle \mathrm{L} B T C$ KAPANIŞ hem de $\triangle$ L BTC HACiM değişkenlerinin durağan olduğunu göstermektedir. KPSS testi, sıfır hipotezinin yapısından kaynaklı olarak istatistiksel olarak anlamsız çıktığı durumlarda serinin durağan olduğuna işaret etmektedir. Ayrıca Q(30) ve Q2(30) test sonuçlarının anlamlı olarak raporlanması serilerde otokorelasyon probleminin varlığına ve ARCH-LM testinin istatistiksel olarak anlamlı raporlanması ise farklı varyans probleminin varlığına işaret etmektedir.

Gözlem sayıları açısından hacim ve kapanış serileri arasında fark olmasının sebebi, işlem hacmine dair serilerin oluşumunda, homojen bir yapı izlenebilmesi için seriden çıkartılan gözlemlerden kaynaklıdır. 29.04.2013 ve 26.12.2013 tarihleri arasında raporlanan hacim verilerinin elde edildiği kripto borsalar sepeti, veri setinin kalanının elde edildiği kripto borsalardan sepetinden farklıdır. Bu nedenle gözlemler seriye dahil edildiğinde yanıltıcı bir suni kırılma oluşturmaktadır. Bununla birlikte logaritmik fark serilerinin gözlem sayısının fiyat ve hacim serilerinin gözlem sayılarından bir gözlem eksik olmasının sebebi değişim serisi olmalarındandır.

Tablo 1'de raporlanan serilerden LTC KAPANIŞ Litecoin kapanış fiyatlarını, LTC HACIM Litecoin piyasa hacmini ve $\Delta \mathrm{L}$ ile başlayan seriler ise söz konusu serilerin her bir gözleminin günlük logaritmik birinci farklarını temsil etmektedir. Litecoin fiyat serisi incelendiğinde, fiyatın en düşük \$1.16 seviyesinden, en yüksek \$358 seviyelerine kadar yükseldiği gözlemlenmektedir. Veri seti içerisine dahil edilen zaman dilimi dahilinde yatırımcısına bire üç yüz kar potansiyeli sunan bu para birimi, kripto para piyasalarının büyüme hızına dair en somut örneklerdendir.

Analizler serilerin logaritmik birinci farkları üzerinde gerçekleştirileceğinden dolayı istatistiksel testler bu seriler üzerinde uygulanmıştır. Serilerin çarpıklık değerleri ele alındığında kapanış fiyatı farkları serisinin sola çarpık, piyasa hacmi serisinin logaritmik farklarının ise sağa çarpık olduğu gözlemlenmektedir. Seriler basıklık değeri açısından ele alındığında, her ikisinin de leptokurtik özellik gösterdiği gözlemlenmektedir. Buna ek olarak Jarque-Bera değerlerinden hareketle serilerin normal dağılıma sahip olmaktan oldukça uzak oldukları sonucuna varılmaktadır.

Logaritmik birinci fark serileri üzerinde uygulanılan durağanlık testi sonuçlarının ADF ve PP testleri için \%1 seviyesinde anlamlı ve KPSS testi sonucuna göre ise istatistiksel olarak anlamsız raporlanması, tutarlı bir şekilde serinin durağan olduğuna işaret eden bulgulardandır. Serilerde otokorelasyon özelliğinin varlığını test etmek amacıyla uygulanan test sonuçlarından $Q(30)$ ve Q2(30) değerlerinin istatistiksel olarak anlamlı olması seride otokorelasyon probleminin varlığına işaret etmektedir. Bununla birlikte, ARCH-LM testi sonuçlarının da anlamlı çıkması bu bulguyu destekler şekilde koşullu değişen varyans etkilerinin varlığına işaret etmektedir.

Ethereum getiri serisinin logaritmik birinci farklarını temsil eden $\Delta$ L ETH KAPANIŞ serisi Jarque-Bera katsayısına göre normal dağılım göstermemektedir. Basıklık değerini incelediğimizde leptokurtik dağılım yapısında olduğu gözlemlenmektedir. Seri ayrıca sola çarpıktır. Tanımlayıcı özellikler, hacim serisinin logaritmik birinci farklarını temsil eden $\triangle \mathrm{L}$ ETH KAPANIŞ değişkeni açısından değerlendirildiğinde değişkenin normal dağılıma yakın bir basıklık derecesine sahip olduğu dikkat çekmektedir. Öte yandan Jarque-Bera değeri dağılım yapısı açısından normal dağılım özelliği göstermediği yönündedir. Sağa çarpık bir dağılım sergilemektedir.

Birim kök testi sonuçları incelendiğinde her iki logaritmik getiri farkı serisinin ADF ve PP testlerine göre \%1 seviyesinde durağan olduğu görülmektedir. KPSS testi kapsamında ise $\Delta \mathrm{L} E T H$ 
KAPANIŞ serisi durağan olarak raporlanırken, $\triangle$ L ETH KAPANIŞ serisi test istatistiğinin \%10 önem seviyesinde anlamlı raporlanmasından dolayı durağan çıkmamıştır. $Q$ testlerinin anlamlı raporlanması ise bu serilerde de otokorelasyon probleminin varlığına işaret etmektedir. ARCH-LM testi bulgularına göre, ARCH etkisi Kapanış serisinde \%1 önem seviyesinde gözlemlenirken Hacim serisinde \%10 önem seviyesinde gözlemlenmektedir. Bu her iki serinin de farklı varyans problemine sahip olduğunu göstermektedir.

Ripple'a dair kapanış fiyatları, piyasa hacmi ve bunların logaritmik birinci farklarının tanımlayıcı istatistiklerinin raporlandığı tablodur. Tanımlayıcı istatistikleri bakımından Ripple, kripto para birimleriyle benzer karakteristik özellikler sergilemektedir. $Q$ istatistiğine bakıldığında seride otokorelasyon probleminin varlığı göze çarpmaktadır. Bununla birlikte ARCH etkisi de her iki seride gözlemlenmektedir. Hem kapanış fiyatlarının logaritmik getiri farklarını temsil eden $\triangle \mathrm{L}$ XRP KAPANIŞ hem de piyasa hacminin logaritmik değişimini temsil eden $\triangle \mathrm{L}$ XRP HACiM serileri, tabi tutuldukları üç durağanlık testinden de durağan oldukları sonucuyla geçmişlerdir. Leptokurtik dağılım sergileyen serilerin ikisi de normal dağılıma yakın bir karakteristik göstermemektedir.

\subsection{Uzun Hafıza Modelleme Süreci}

Çalışmada olgun kripto para piyasalarının etkinliğini incelemek amacıyla uzun hafızayı dikkate alan koşullu varyans modellerinden yararlanılmıştır. Bu amaçla ilk olarak BITCOIN getiri serisinin ( $\triangle$ L BTC KAPANIŞ) uzun hafıza özelliği gösterip göstermediği incelenmiştir. BITCOIN getiri serisine ( $\triangle \mathrm{L}$ BTC KAPANIŞ) ilişkin uzun hafıza ölçüsünü gösteren $\mathbf{d}$ katsayısı 0.2381 olarak elde edilmiştir. $d$ parametresinin $0<d<0.5$ arasında olması nedeniyle, BITCOIN getiri serisinin ( $\triangle$ L BTC KAPANıŞ) uzun hafızaya sahip olduğu ve gözlemleri arasında pozitif bağımlılığı olduğu ifade edilebilir. BITCOIN getiri serisinin ( $\triangle \mathrm{L}$ BTC KAPANIŞ) uzun hafızaya sahip olması nedeniyle, bu seriye ait uygun ARFIMA modeli belirlenmeye çalışılmıştır. Uygun model belirlenirken bilgi kriterlerinden yararlanılmıştır. $\triangle \mathrm{L}$ LTC KAPANIŞ ve $\triangle \mathrm{L}$ LTC HACIM serilerinde ARCH etkilerinin bulgulanmasıyla, volatilite modelleme sürecinde GARCH türevi modelleri uygulanmasının yolu açılmıştır. Serilerin uzun hafıza özelliğini test etme amacıyla ARFIMA modelleri uygulanmıştır. Uzun hafıza özelliğine işaret eden bulguların elde edilmesinden dolayı, Ethereum a ait seriler de ARFIMA yöntemiyle modellenmiştir. $d$ parametresinin ARFIMA modellerinin tamamında 0 ile 0.5 arasında raporlanmasıyla uzun hafıza etkisinin varlığı doğrulanmıştır. Bu durum, serinin gözlemleri içerisinde pozitif bağımlılık olduğu anlamına gelmektedir. ARFIMA sürecinde kullanılacak model, Log-olabilirlik ve Akaike bilgi kriterine göre $\operatorname{ARFIMA}(3,1,3)$ olarak seçilmiştir. Ripple a ait serilerde de uzun hafıza özelliğinin varlığını işaret eden otokorelasyon bulgularına rastlanmasıyla serilerin ARFIMA süreciyle modellenmesine karar verilmiştir. Alternatif ARFIMA modellerine katsayı tahmin sonuçları ve özet istatistikler Tablo 2'de yer almaktadır.

Tablo 2: $\operatorname{ARFIMA}(p, 1, q)$ Modelleri Tahmin Sonuçları

\begin{tabular}{ccccc}
\hline \hline & $\begin{array}{c}\text { BITCOIN } \\
\text { ARFIMA(3,1,2) }\end{array}$ & $\begin{array}{c}\text { LITECOIN } \\
\text { ARFIMA(2,1,1) }\end{array}$ & $\begin{array}{c}\text { ETHEREUM } \\
\text { ARFIMA(3,1,3) }\end{array}$ & $\begin{array}{c}\text { RIPPLE } \\
\text { ARFIMA(3,1,2) }\end{array}$ \\
\hline \hline d & $0.06948^{* * *}$ & $0.119095^{* * *}$ & 0.042768 & $0.112387^{* * *}$ \\
& $(0.02849)$ & $(0.05043)$ & $(0.196)$ & $(0.0001)$ \\
AR-1 & $0.66969 * * *$ & $1.45004 * * *$ & $-0.59065^{* * *}$ & 0.320695 \\
& $(0.04441)$ & $(0.08862)$ & $(0.0000)$ & $(0.0001)$ \\
AR-2 & $-0.91264 * * *$ & $-0.11313^{* *}$ & $-0.65685^{* * *}$ & -0.8807 \\
& $(0.03519)$ & $(0.03381)$ & $(0.0000)$ & $(0.0000)$ \\
AR-3 & $-0.06788^{* *}$ & & $-0.7406 * * *$ & -0.06045 \\
& $(0.03642)$ & & $(0.0000)$ & $(0.143)$
\end{tabular}


Eskişehir Osmangazi Üniversitesi iißBF Dergisi

\begin{tabular}{ccccc} 
MA-1 & $-0.73565^{* * *}$ & $-1.48109^{* * *}$ & $0.615891^{* * *}$ & -0.38241 \\
& $(0.02544)$ & $(0.0673)$ & $(0.0000)$ & $(0.0000)$ \\
MA-2 & $0.928424^{* * *}$ & & $0.673664^{* * *}$ & 0.872627 \\
& $(0.02702)$ & & $(0.0000)$ & $(0.0000)$ \\
MA-3 & & $0.808151^{* * *}$ & $(0.0000)$ \\
\hline Sabit & 0.002298 & 0.000482 & $0.003324^{* *}$ & 0.001296 \\
& $(0.0015)$ & $(0.0012)$ & $(0.0200)$ & $(0.464)$ \\
\hline Q(50) & $47.819^{*}$ & $50.570^{* *}$ & 24.685 & $161.98^{* * *}$ \\
ARCH-LM(2) & $92.880^{* * *}$ & $28.086^{* * *}$ & $36.539^{* * *}$ & -3.85227 \\
Akaike & -3.37699 & -4.42752 & -4.02493 & 3176.489 \\
\hline Log-Olabilirlik & 2951.444 & 3328.539 & 1842.13 & \\
\hline \hline
\end{tabular}

Not: ${ }^{* * *}, * * *$ sırasıyla \%10, \%5 ve \%1 önem düzeylerinde anlamlılıkları ifade etmektedir. Parantez içindeki değerler standart hataları göstermektedir.

Tablo 2'de alternatif ARFIMA(p,1,q) modelleri incelendiğinde, Akaike bilgi kriteri ve log-olabilirlik kriterine göre Bitcoin serisi için en uygun model $\operatorname{ARFIMA}(3,1,2)$ olarak seçilmiştir. Litecoin için ise, $\triangle$ L LTC KAPANIŞ serisinin d katsayısının ARFIMA sürecinin her tahmininde 0 ile 0.5 değeri arasında raporlanmış olması seride uzun hafıza özelliğinin varlığına işaret etmektedir. Seride uzun hafıza etkisinin varlığına dair sonuçlar elde edildiğinden dolayı modelleme sürecine AR$\operatorname{FIMA}(p, 1, q)$ modelleriyle devam edilmiştir. Log-olabilirlik değeri mümkün olduğunca yüksekken Akaike bilgi kriteri değerlerinin mümkün olduğunca düşük olmasına dikkat edilerek, Litecoin için en uygun $\operatorname{ARFIMA}(p, 1, q)$ modeli $\operatorname{ARFIMA}(\mathbf{2}, \mathbf{1}, \mathbf{1})$ olarak tespit edilmiştir. Aynı kriterler gözetilerek Ethereum için $\operatorname{ARFIMA}(3,1,3)$, Litecoin için ise $\operatorname{ARFIMA}(3,1,2)$ modelleri tercih edilmiştir.

ARCH-LM testi sonucuna göre, modelde $A R C H$ etkisinin olduğu görülmektedir. Bu nedenle çalışmaya, koşullu değişen varyans modelleri ile devam edilmiştir.

\subsection{Volatilite Yapısının Modelleme Süreci}

Volatilite modelleme sürecinde, modellenilen varlığın finansal niteliği kullanılacak GARCH yöntemini belirleme konusunda etkilidir. Kripto para birimlerine özel bir volatilite modelleme yöntemi oluşturulmadığından, yabancı para birimi, emtia veya gayrimenkul fiyat serilerinde kullanılan bir çok yöntem denenmiştir(FIGARCH, FIAPARCH, FIGARCH CHUNG, FIEGARCH, FIEGARCH BBM). Bu modellerden FIGARCH, FIEGARCH ve FIAPARCH kripto para birimi serilerinde anlamlı sonuçlar verebilmiştir. Kripto para birimi getiri serilerinin uzun hafızayı dikkate alarak volatilite yapısını ve işlem hacminin volatilite yapısı üzerindeki etkisini ortaya koymak amacıyla en uygun sonuçların olgun kripto para birimleri için FIEGARCH yöntemi ile elde edildiği gözlenmiştir. Tablo 3 içerisinde bu kripto para birimlerinin FIEGARCH yöntemiyle oluşturulan volatilite modelleri raporlanmıştır.

Tablo 3: Olgun Kripto Para Birimlerine ilişkin Volatilite Modelleri

\begin{tabular}{|c|c|c|c|c|}
\hline Değiş̧enler & $\begin{array}{l}\text { BITCOIN } \\
\text { FIEGARCH }\end{array}$ & $\begin{array}{l}\text { LITECOIN } \\
\text { FIEGARCH }\end{array}$ & $\begin{array}{l}\text { ETHEREUM } \\
\text { FIEGARCH }\end{array}$ & $\begin{array}{c}\text { RIPPLE } \\
\text { FIEGARCH }\end{array}$ \\
\hline Cst(M) & $\begin{array}{c}0,000577 \\
(0,2831)\end{array}$ & $\begin{array}{c}-0,000504 \\
(0,0519)\end{array}$ & $\begin{array}{c}-0.000894 \\
(0.0413)\end{array}$ & $\begin{array}{c}-0.002276 * * * \\
(0.0000)\end{array}$ \\
\hline d-Arfima & $\begin{array}{c}0,174499^{*} \\
(0,0951)\end{array}$ & $\begin{array}{c}0.143727^{*} \\
(0.07991)\end{array}$ & $\begin{array}{c}0.149827 * \\
(0.07882)\end{array}$ & $\begin{array}{c}0.0757746^{* * * *} \\
(0.0000)\end{array}$ \\
\hline$A R(1)$ & $\begin{array}{c}0,201475 \\
(0,7619)\end{array}$ & $\begin{array}{c}0,175328 \\
(0,0015)\end{array}$ & $\begin{array}{c}0.517475 \\
(0.5028)\end{array}$ & $\begin{array}{c}-0.156836 * * * \\
(0.0000)\end{array}$ \\
\hline$A R(2)$ & $\begin{array}{c}0,150003 \\
(0,4627)\end{array}$ & $\begin{array}{c}-0,036344 \\
(0,1194)\end{array}$ & $\begin{array}{c}0.144068 \\
(0.8301)\end{array}$ & $\begin{array}{c}0.108153^{* * *} \\
(0.0000)\end{array}$ \\
\hline$A R(3)$ & $\begin{array}{c}0,039254 \\
(0,5133)\end{array}$ & & $\begin{array}{c}-0.221500 \\
(0.1840)\end{array}$ & $\begin{array}{c}-0.012834^{* * *} \\
(0.0000)\end{array}$ \\
\hline
\end{tabular}


Ağustos 2019, C. 14, S. 2

\begin{tabular}{ccccc} 
MA(1) & $-0,454606$ & $-0,307373$ & -0.624962 & $0.087584^{* * *}$ \\
& $(0,5273)$ & $(0.0000)$ & $(0.4176)$ & $(0.0000)$ \\
MA(2) & $-0,200625$ & & -0.084537 & $-0.205303^{* * *}$ \\
& $(0,5698)$ & & $(0.9097)$ & $(0.0000)$ \\
\hline Cst(V) x 10^4 & $673,37^{* * *}$ & $-85129,20615$ & 0.231241 & $-190.951 .301^{* * *}$ \\
& $(0.000)$ & $(0,2704)$ & $(0.2450)$ & $(0.0000)$ \\
Btcvolume (V) & $-4,524007^{* * *}$ & $-4,462461$ & $--0.439147^{* * *}$ & $0.751317^{*}$ \\
& $(0.000)$ & $(0.000)$ & $(0.0000)$ & $(0.0849)$ \\
d-Figarch & $0,638903^{* * *}$ & $0,681781^{* * *}$ & -4.839279 & $-0.500445^{* * *}$ \\
& $(0.0000)$ & $(0.0000)$ & $(0.0000)$ & $(0.0000)$ \\
ARCH(Phi1) & $0,877624^{* * *}$ & $0,960468^{* * *}$ & $0,662781^{* * *}$ & $0.398894^{* * *}$ \\
& $(0.0000)$ & $(0.0000)$ & $(0.0000)$ & $(0.0052)$ \\
GARCH(Beta1) & $-0,617861^{* * *}$ & $-0,639365^{* * *}$ & $0.213527^{* * *}$ & $0.037671^{* * *}$ \\
& $(0.0001)$ & $(0.0000)$ & $(0.0000)$ & $(0.0959)$ \\
EGARCH(Theta1) & $0,19175^{* * *}$ & $0,097974 * *$ & $0.966809 * * *$ & $0.939428^{*}$ \\
EGARCH(Theta2) & $(0,0000)$ & $(0,0245)$ & $(0.0000)$ & $(0.0879)$ \\
GED parametresi & $0,61164 * * *$ & $0,645934^{* * *}$ & $-0.127082^{* * *}$ & $0.751317^{* * *}$ \\
ARCH-LM (5) & $(0.0000)$ & $(0.0000)$ & $(0.0000)$ & $(0.0000)$ \\
Box Pierce & $1,204543^{* * *}$ & $3,566157^{* * *}$ & 2.043300 & $0.710601^{* * *}$ \\
Q testi (50) & $(0.0000)$ & $(0.0000)$ & $(0.0000)$ & $(0.0000)$ \\
Akaike & $0.3038[0.9108]$ & $0.1593[0.9272]$ & $1.521063[0.21]$ & $0.07148[0.7892]$ \\
Schwarz & $64.5558[0.294]$ & $73,9553[0.0072]$ & $73,213[0.0052]$ & $83.076^{*}[0.065]$ \\
Log-olabilirlik & -4.619674 & -5.826974 & -4.992838 & -4.942436 \\
\hline \hline
\end{tabular}

Not: $* * * * *$,*sırasıyla \%10, \%5 ve \%1 önem düzeylerinde anlamlılıkları ifade etmektedir. Parantez içindeki değerler olasılık düzeylerini göstermektedir. EGARCH(Theta1) işaret etkisini, EGARCH(Theta2) büyüklük etkisini, APARCH( $\delta$ ) volatilite yapısındaki güç terimini, APARCH $(\lambda)$ volatilitedeki asimetri etkisini ifade etmektedir.

BITCOIN getiri serisine ilişkin FIGARCH, FIEGARCH ve FIAPARCH modelleri arasında, Akaike ve Schwarz bilgi kriterlerine ve log-olabilirlik kriterine göre en uygun model ARFIMA(3,1,2)-FI$\operatorname{EGARCH}(1,1,1)$ modeli seçilmiştir. Analiz sonuçlarında ilk dikkat çeken nokta Btcvolume \%1 anlamlılık seviyesinde, kuvvetli bir şekilde negatif katsayıya sahip olmasıdır. Bu katsayı işlem hacmi ve piyasa volatilitesi arasında kuvvetli bir ters yönlü ilişkiye işaret etmektedir. Dolayısıyla yıllar içerisinde piyasa derinliği arttıkça volatilitenin azaldığı hipotezi red edilememektedir.

Modelde ARCH ve GARCH parametreleri anlamlı olduğu görülmektedir. EGARCH(Theta1) katsayısı işaret etkisini, EGARCH(Theta2) katsayısı ise büyüklük etkisini göstermektedir. İşaret etkisini gösteren katsayı pozitif ve anlamlıdır. Bu durum, negatif haberlerin oynaklık üzerinde pozitif haberlere göre daha etkili olduğunu ifade etmektedir. Aynı zamanda büyüklük etkisi de pozitif ve istatistiksel açıdan anlamlıdır. Pozitif bir büyüklük etkisi, gerçekleşen durumların beklenen durumlardan daha etkili olduğunu göstermektedir. İşaret ve büyüklük etkileri birlikte ele alındığında, gerçekleşen durumların Bitcoin fiyat getiri oynaklığı üzerinde negatif haberlere göre daha yüksek bir etki yarattığı söylenebilir. Diğer bir ifadeyle beklentiler manipüle edilmeye çaıışılmaktadır. Beklentiler gerçekleşmediği için piyasanın etkin olduğu ifade edilebilmektedir.

ARFIMA(2,3)-FIEGARCH(1,1) modelinin artıklarına uygulanan ARCH-LM testi sonucunda ARCH etkisinin ortadan kalkmış olması modelin doğru uygulandığını göstermektedir. Model tahmininde GED dağılımından yararlanılmıştır. GED dağıımının seçilmesinin nedeni serinin asimetrik dağılım özelliği göstermesidir. ARFIMA(2,3)-FIEGARCH(1,1) modelinde otokorelasyon probleminin ortadan kalkıp kalkmadığı $Q$ istatistikleri açısından incelenmiştir. $Q$ istatistikleri incelendiğinde otokorelasyonun uzun gecikme düzeylerinde dahi ortadan kalktığı görülmektedir. Bu durum, uzun hafıza özelliğinin varlığına işaret etmektedir. 
Koşullu varyans serisi, volatilite modelleme sürecinde elde edilen seri içerisinden rassal olarak alınan gözlemlerin, modelin tahminleme aralığı ile farklarını ifade etmektedir. Koşullu varyansın yüksek olduğu dönemler, çalışma kapsamında modellenen volatilite yapısından sapmaların sıklıkla yaşandığı dönemler olarak ifade edilebilir. Bu dönemlerde piyasaların genellikle beklenmedik dışsal şoklara maruz kaldığı gözlemlenir.

Şekil 1: Bitcoin'e ait Koşullu Varyans Grafiği

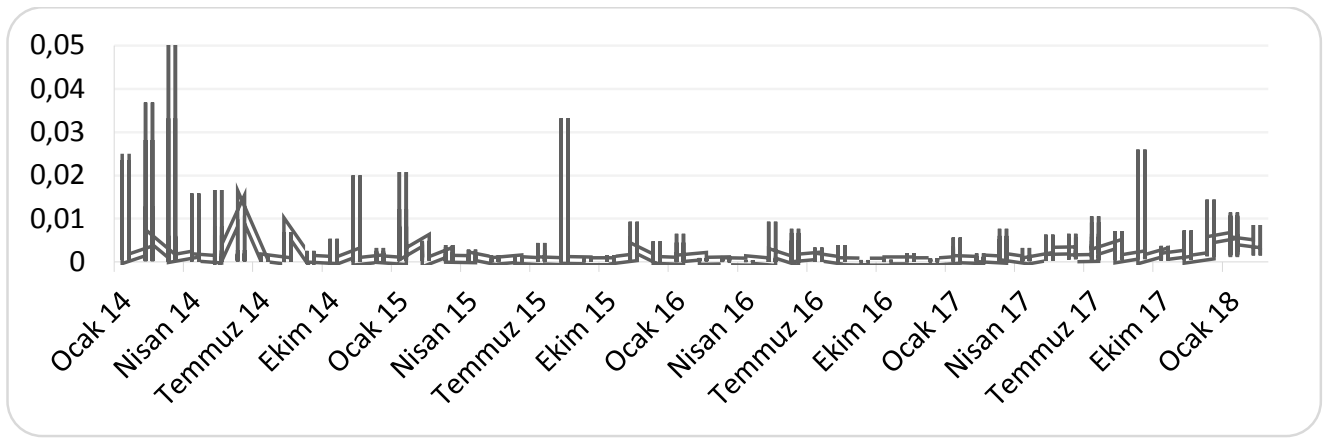

Bitcoin fiyat serisi için oluşturduğumuz koşullu varyans grafiği içerisinde varyansın yüksek olduğu noktaların, piyasaları etkileyen tarihsel şoklarla açıklanabilir olması modelin ekonomik anlamlılı̆ı açısından önemlidir. Şekil 1 incelendiğinde 2014 yılı Ocak ayı itibariyle koşullu varyansın oldukça yüksek seyrettiğini gözlemlenebilir. 2014 yılı tüm kripto para piyasalarında "Büyük Buhran" etkisi yaratan Mt Gox borsasının sanal hırsızlar tarafından hacklenmesi ve sonrasında iflas etmesi olayları ile ciddi bir kırılma noktası olarak bilinmektedir. Tüm kripto para piyasalarının \%70 lik kısımından fazlasını elinde tutan borsanın iflası, hali hazırda sığ olan piyasanın büyük bir çöküş yaşamasını tetiklemiştir. 2015 yılı başına kadar normalleşme süreci yaşayan piyasalarda Ethereum para biriminin piyasaya sürülmesi ve sonrasında Coinbase isimli borsanın hacklenmesi ile iki şiddetli şok daha yaşanmıştır. 2017 Ekim ayına kadar ciddi bir şokun gözlemlenmediği Bitcoin piyasasında SegWit krizinin yarattığı tedirginlik ile orta şiddette bir dalgalanma yaşanmış, fakat sonrasında kısa sürede normalleşme sağlanmıştır.

Litecoin verileri incelendiğinde ise, uygulanan FIGARCH, FIEGARCH ve FIAPARCH modelleri arasından en uygun model ARFIMA $(2,1,1)$-FIEGARCH $(2,1,1)$ olarak seçilmiştir. ARFIMA seçim sürecindekine benzer şekilde en uygun model seçimi, yüksek log-olabilirlik ve düşük Akaike ve Schwarz bilgi kriterleri baz alınarak yapılmıştır.

Araştırma sorusu olan hacim ve volatilite arasındaki ilişkiyi açıklayan Ltcvolume (V) parametre tahmini istatistiksel olarak \%1 seviyesinde anlamlı ve kuvvetli bir şekilde negatif olarak raporlanmıştır. Bu durum Litecoin için piyasa hacmi arttıkça volatilitenin azaldığını göstermektedir. Geçmiş şokların etkisini temsil eden ARCH(Phi1) parametre tahmininin istatistiksel olarak \%1 seviyesinde anlamlı olması ve katsayısının 1 e yakın olması geçmiş şokların etkisinin güçlü olduğunu ve oynaklığı temsil eden GARCH(Beta1) parametre tahminlerinin anlamlı ve negatif çıkması ise etkinin kalıcılığını zayıf olduğunu göstermektedir.

Modelde asimetrik etkiyi ölçen EGARCH(Theta1) katsayısının pozitif ve anlamlı olması seride negatif haberlerin yarattığı şokların etkisinin pozitif haberlere oranla daha şiddetli olduğunu gösterir. Büyüklük etkisini temsil eden EGARCH(Theta2) parametre tahmininin pozitif ve anlamlı 
olması ise spot şokların piyasa beklentilerine oranla daha büyük etkiye sahip olduğunu göstermektedir. Buna ek olarak Theta 2 katsayısının Theta 1 katsayısına oranla daha büyük olması, Bitcoin serisindekine benzer şekilde manipülasyon teşebbüslerine işaret etmektedir.

ARFIMA(2,1,1)-FIEGARCH(2,1,1) modeli ARCH-LM sonuçlarına göre ARCH etkisi ortadan kalkmıştır. Bu, modelin doğru uygulandığına dair bir işaret olarak yorumlanabilir. Otokorelasyon problemini Box Pierce $Q(50)$ testi üzerinden incelediğimizde ise, problemin ortadan kalktığı görülmektedir. Modelde GED dağılımı kullanılmasının nedeni serinin asimetrik dağılıma sahip olmasıdır.

Şekil 2: Litecoin'e ait Koşullu Varyans Grafiği

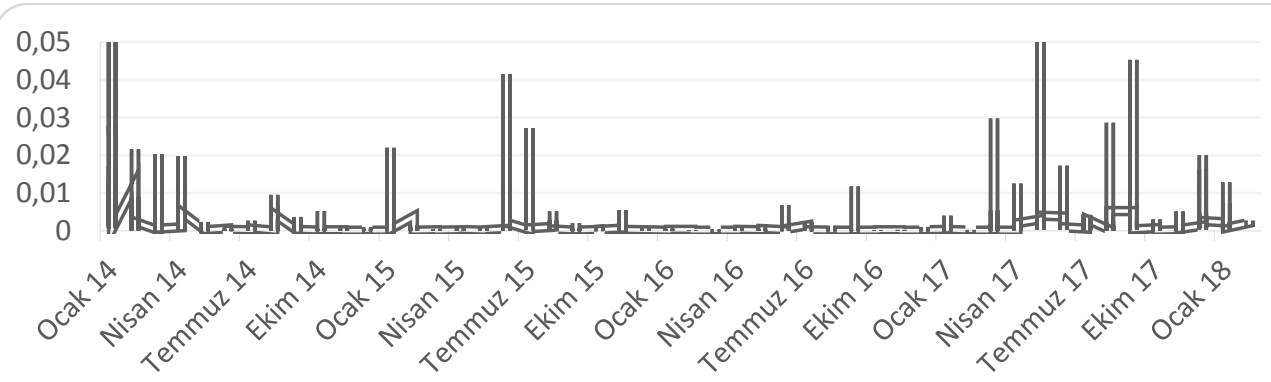

Litecoin serisi için koşullu varyans grafiğini incelediğimizde, varyans tahminlerinin modelden saptığı 3 ana dönem göze çarpmaktadır. Bu dönemler Bitcoin serisinin sapmalar yaşadığı dönemlerle aynı zaman dilimlerine denk gelmektedir. Bunlar içerisinden 2014 yılının Ocak ayı Bitcoin e benzer şekilde Mt Gox borsasının hacklenmesine ve iflas etmesine denk gelmektedir. Ocak 2015 e kadar düşük seyreden koşullu varyans 2015 Ocak ayında Ethereum un piyasaya çıkmasıyla ufak ölçekte bir sapma yaşamıştır. Temmuz 2015 de Coinbase borsasının hacklenmesi Litecoin piyasasında da volatilitenin beklenenin üzerinde seyretmesine neden olmuştur. 2017 yılı Nisan ayında başlayan ve 2018 başına kadar süren SegWit krizinin etkileri Litecoin koşullu volatilite serisinde de hareketlenmeye yol açmıştır. Öte yandan Litecoin serisi Ekim 2017 dönemine denk gelen Bitcoin Cash "Hard Fork" undan da belirgin derecede etkilenmiştir.

Ethereum serisine uygulanan modeller içerisinde, Log-olabilirlik, Akaike ve Schwarz bilgi kriterlerine göre en uygun model ARFIMA(3,1,3)-FIEGARCH modeli olmuştur. Modelde yer alan Ethvolume (V) isimli değişken Ethereum kripto para biriminin piyasa hacim serisini temsil etmektedir. Şu ana kadar analiz edilen tüm kripto para birimlerinin volatilite yapısı tutarlı bir şekilde FIEGARCH modeli ile uyumlu raporlanmıştır. FIEGARCH modeli parametre tahminleri incelendiğinde, araştırma sorusunu temsil eden Ethvolume değişkeninin kuvvetli negatif katsayıya ve \%1 önem seviyesinde istatistiksel anlamlılığa sahip olduğu görülmektedir. Bu parametre tahmini, hacim ve oynaklık arasında kuvvetli ve ters yönlü bir ilişki olduğuna işaret etmektedir. Bu bulgu diğer kripto para serilerinde de raporlanan etkinlik ve volatilite arasındaki ters yönlü ilişkiyi doğrular niteliktedir. Öte yandan, bu parametre tahmininin sağlamasını yapmak amacıyla ARCH etkisinin ortadan kalktığını doğrulamak gerekmektedir. Bu amaçla ARCH-LM test sonucunu incelediğimizde istatistiksel olarak anlamsız olduğu görülmektedir. Bu durum modelin doğru uygulandığını ve Ethvolume parametre tahminin geçerli olduğunu göstermektedir. Bununla birlikte otokorelasyon probleminin ortadan kalkıp kalkmadığını tespit etme amacıyla Box 
Pierce $Q$ testi ellinci gecikmeye kadar uygulandığında, otokorelasyon problemi ortadan kalkmaktadır. Bu test sonucu uzun hafıza özelliğinin uzun dönemde ortadan kalkmaya başladığına dair bir işaret olarak yorumlanabilir.

FIEGARCH modeli süreç bileşenlerinden EGARCH(Theta1) ve EGARCH(Theta2) incelendiğinde her ikisinin de \%1 önem seviyesinde anlamlı olduğu dikkat çekmektedir. İşaret etkisini gösteren Theta1 katsayısının negatif olması, seride pozitif haberlerin etkisinin negatif haberlere göre daha yüksek olduğunu göstermektedir. Bu, genellikle boğa piyasası koşullarında rastlanan ve nadir gözlemlenen bir asimetrik etkidir. Genel yatırımcı psikolojisinin aksine olan bu davranışa sadece Ethereum serisinde rastlanılmıştır. Pozitif haberlerin piyasada daha etkili olduğu yönünde yorumlanan bu asimetrik etkinin varlığı, Ethererum piyasası yatırımcılarının risk toleranslarının diğerlerine oranla daha yüksek olması ile açıklanabilir.

Theta 2 parametre tahminine ait katsayının pozitif yönlü olması ise piyasada gerçekleşen durumların piyasa beklentilerine oranla daha etkili olduklarını göstermektedir. Bu bulgunun Theta1 parametre tahminiyle birlikte yorumlanması sonucunda, piyasa uygulanan dışsal müdahalelerin yapay olumlu haberler şekilde gerçekleştiği sonucunda varılmaktadır. Diğer bir deyişle, müdahaleler manipülatörler pozisyon aldıktan sonra gerçekleştirilmektedir. Diğer serilerde olduğu gibi bu seride de asimetrik dağılım özellikleri gözlemlendiğinden modelleme süreci GED dağılımı kullanılarak gerçekleştirilmiştir.

Şekil 3: Ethereum'a ait Koşullu Varyans Grafiği

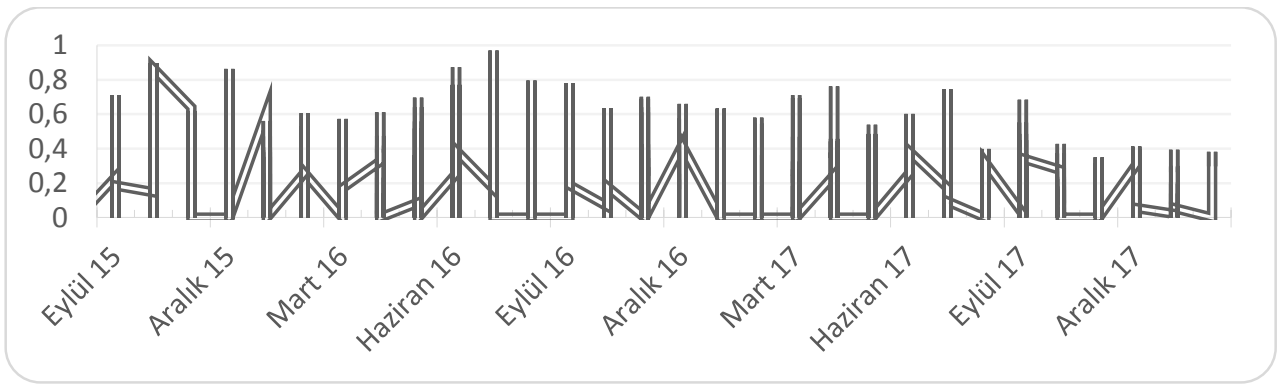

Ethereum serisinin koşullu varyans grafiğini gösteren Şekil 14 incelendiğinde, serinin pozitif yönlü asimetrik dağılımı ve FIEGARCH sürecinde tahminlenen Theta1 ve 2 parametrelerinin ortaya koyduğu pozitif yönlü manipülasyon şemasının koşullu varyans üzerinde de dikkat çekmektedir. Bu durumun en net ifadesi tarihler arasındaki koşullu volatilite dağılımlarının ani tekil sıçramalardan değil, çok sayıda ve birbirini izleyen küçük sıçramalar seklinde gözlemlenmesidir. Diğer bir deyişle, Ethereum koşullu varyans serisi, diğer serilerdeki gibi belirli aralıklarla büyük sapmalar yaşamaktansa daha tutarlı bir koşullu varyans grafiği sergilemektedir. Koşullu varyans dahilinde gerçekleşen ani sıçramaların manipülatif etkilerle açıklanmasından dolayı serinin manipülasyonlara karşı daha dirençli olduğunu söylemek mümkündür. Bu durumun muhtemel sebeplerinden birisi, piyasayı etkileyecek çapta büyük krizler haricinde Ethereum kripto kara biriminin kendisine dair büyük bir skandalın ortaya çıkmamış olmasıdır.

Log-olabilirlik, Akaike ve Schwarz bilgi kriteri sonuçlarına dayanarak Ripple volatilite yapısını modellemek için en uygun yöntemin $\operatorname{ARFIMA}(3,1,2)$-FIEGARCH modeli olduğuna karar verilmiştir. Hacim parametre tahminini incelemeden önce modelin doğru uygulandığını teyit etme amacıyla ARCH-LM testi ve Box Pierce $Q$ incelendiğinde ARCH etkisinin ortadan kalktığı ve uzun serilerde otokorelasyon probleminin de çözüldüğü görülmektedir. Araştırma sorusunun cevabını veren Ripplevolume (V) parametre tahmini incelendiğinde, \%10 önem seviyesinde istatistiksel 
anlamlııık değerine ve pozitif bir katsayıya sahip olduğu gözlemlenmektedir. Bu durum diğer tüm kripto para birimlerinde tutarlı bir şekilde bulunan kuvvetli negatif yönlü ilişki ile uyuşmamaktadır. Ripple'ın kripto para birimlerine dair hemen hiçbir karakteristik özelliği taşımaması bu bulgunun en muhtemel sebebidir.

Modelin Theta katsayılarını incelendiğinde, işaret etkisini gösteren Theta1 katsayısının da büyüklük etkisini gösteren Theta2 katsayısının da anlamlı ve pozitif oldukları görülmektedir. Analiz sürecinde ilk defa karşılaşılan başka bir nokta Theta1 katsayısının \%10 önem seviyesinde anlamlı çıkmasıdır. Bu durum, seride asimetrik etki varlığının diğer serilere oranla istatistiksel olarak daha az belirgin olduğunu ifade etmektedir. Theta1 katsayısının pozitif olması, negatif haberlerin pozitif haberlere göre daha büyük ve asimetrik etkiye sahip olduğunu göstermektedir. Theta 2 parametre tahmini ele alındığında, \%1 önem seviyesinde istatistiksel anlamlılığa ve kuvvetli bir katsayıya sahip olduğu raporlanmıştır. Bu durum, fiyatlar üzerinde neredeyse sadece spot şokların etkili olduğu ve gelecek beklentilerinin çok daha az etkili olduğunu göstermektedir. Diğer kripto para birimlerinde 0.24 ile 0.64 arası değişen spot olaylar ve gelecek beklentilerinin piyasaya etki oranı, Ripple için 0.75 seviyelerine ulaşmaktadır.

Bulgular bir bütün olarak ele alındığında piyasanın yoğun bir şekilde müdahaleye uğradığı izlenimi oluşmaktadır. Ripple piyasasında fiyatların oluşumunda gelecek beklentilerinin rolü sıfıra yakın raporlanmıştır. Böyle bir durum, paranın tüm kontrolünün özel bir şirkete ait olduğu bir piyasa için beklenmedik değildir.

Şekil 4: RIPPLE'a ait Koşullu Varyans Grafiği

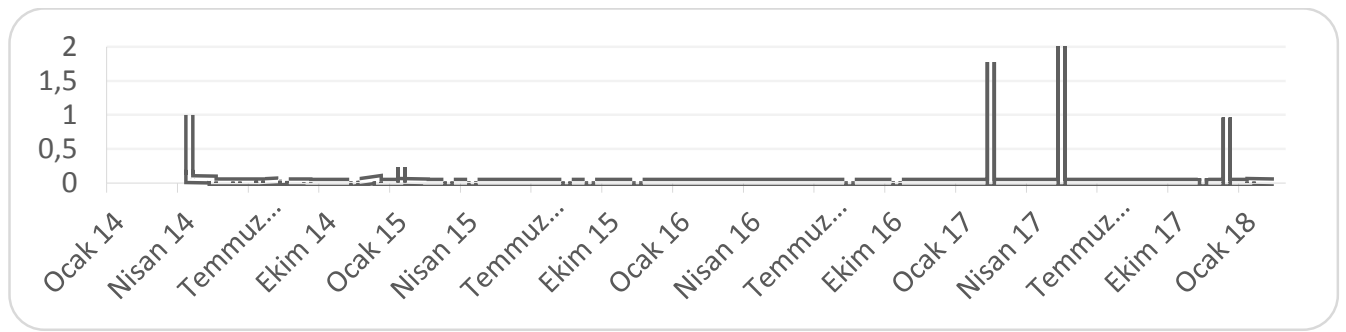

Koşullu varyans grafiği bir bütün olarak incelendiğinde ilk dikkat çeken nokta, büyük kriz dönemleri haricinde piyasada koşullu varyansın sıfır olmasıdır. 2014 yılındaki Mt Gox şoku, 2015 yılındaki Bitstamp şoku ve 2017 deki SegWit şokları etkileri belirgin bir şekilde gözlemlenebilirken, tüm bu büyük şokların etkileri sadece bir dönem sonra sıfırlanmaktadır. Bu durum piyasa volatilitesinin düşük olduğu yönünde bir izlenim yaratsa da altında yatan sebep piyasa volatilitesi değil, piyasa müdahalesidir. Bu kadar kusursuz bir koşullu varyans yapısına kripto para piyasaları gibi volatil bir ortamda sahip olmak, doğal koşullar altında mümkün değildir. Ripple'ın kendini düzenleyen ekonomik altyapısının, kendisinden çok daha detaylı ekonomik yapıya sahip kripto paralar karşısında bu kadar ezici üstünlüğe sahip olması doğal yollarla gerçekleşmiş olamaz. Tüm analiz ettiğimiz kripto paralar içerisinde en farklı karakteristik özellikleri gösteren seri Ripple'a aittir. Kendi fiyatını bulmayan çalışan bir piyasadan ziyade, sanal bir portföyü andıran seri yapısı, Ripple'ın merkezi olarak kontrol edildiğine dair şüphe uyandırmaktadır.

\subsection{Genç Piyasalarda Uzun Hafıza ve Asimetrik Etki Testleri}

Araştırma kapsamında piyasaya yeni sunulmuş olan NEO, Cardano, MIOTA ve Bitcoin Cash verileri de analiz edilmiştir. Bu kripto para birimleri hem teknolojik altyapı hem de ekonomik alt yapı olarak birbirinden oldukça farklı yapıya sahiptirler. Temel amaçları piyasada büyük ha- 
cimde işlem gören kripto para birimlerinin karşılaşmakta olduğu sorunları barındırmayan sistemler yaratmaktır. Örneğin kuantum teknolojisinde işlemci gücüne sahip bilgisayarlar piyasaya çıktığında Bitcoin ve Litecoin'in tamamen kullanım dışı kalması öngörülmektedir. IOTA, kuantum bilgisayarların var olduğu bir sistemde dahi sorunsuz çalışabilecek bir teknolojik alt yapıyla tasarlanmıştır. Başka bir büyük yapısal farkı ise sistemin madenciliğe ihtiyaç duymadan çalışmasıdır. Bu para birimleri henüz yeterli kullanıcıya ulaşamadıkları veya var olan kullanıcılardan henüz yeterli talep görmediklerinden dolayı modellenmesi oldukça zor para birimleridir. Veri setlerinin toplanmasında diğer kripto para birimlerinde kullandığımız yöntemin aynısı kullanılmıştır. Kullanılan veri setlerine dair tanımlayıcı istatistikler aşağıdaki gibidir:

Tablo 4: ADA, NEO, BCH ve MIOTA Kripto Para Birimlerine ilişkin Tanımlayıcı İstatistikler

\begin{tabular}{|c|c|c|c|c|}
\hline & $\Delta \mathrm{L} A \mathrm{ADA}$ & $\Delta \mathrm{L}$ NEO & $\Delta \mathrm{L} B C H$ & $\Delta \mathrm{L}$ MIOTA \\
\hline Ortalama & 0.009229 & 0.006195 & 0.003212 & 0.002471 \\
\hline Medyan & 0.001534 & -0.000771 & -0.001900 & 0.000560 \\
\hline Maksimum & 0.374163 & 0.347942 & 0.187434 & 0.166751 \\
\hline Minimum & -0.125374 & -0.200190 & -0.137381 & -0.163749 \\
\hline Std. Sapma & 0.068606 & 0.049767 & 0.048918 & 0.048371 \\
\hline Çarpıklık & 2.260193 & 1.480113 & 0.847185 & 0.265691 \\
\hline Basıklık & 11.66694 & 12.48129 & 5.971535 & 4.811411 \\
\hline Jarque-Bera & $453.8613^{* * *}$ & $1874.500^{* * *}$ & $85.80670^{* * *}$ & $33.55699^{* * *}$ \\
\hline ADF & $-5.995780^{* * *}$ & $-21.17098^{* * *}$ & $-11.6897^{* * *}$ & $-13.84748^{* * *}$ \\
\hline PP & $-10.63465^{* * *}$ & $-21.20214^{* * *}$ & $-11.60461^{* * *}$ & $-13.88083^{* * *}$ \\
\hline KPSS & 0.184722 & 0.181939 & 0.177152 & 0.135235 \\
\hline$Q(30)$ & $49.139^{* * *}$ & $44.476^{* *}$ & 17.055 & 19.138 \\
\hline$Q^{2}(30)$ & $48.835^{* * *}$ & $244.10^{* * *}$ & $43.388^{* *}$ & $44.751^{* *}$ \\
\hline ARCH-LM & $2.866747^{* * *}$ & $61.69673^{* * *}$ & $20.86087^{* * *}$ & $6.49249^{* * *}$ \\
\hline \multirow[t]{2}{*}{ Gözlem Sayısı } & 114 & 456 & 176 & 226 \\
\hline & $\triangle \mathrm{L}$ ADA & $\Delta \mathrm{L}$ NEO & $\triangle \mathrm{LBCH}$ & $\Delta \mathrm{L}$ MIOTA \\
\hline Ortalama & -0.015066 & -0.006778 & 0.001974 & -0.005299 \\
\hline Medyan & 0.025126 & 0.020242 & 0.019833 & 0.016752 \\
\hline Maksimum & 0.593312 & 0.909364 & 0.722424 & 0.583564 \\
\hline Minimum & -0.782061 & -1.127231 & -1.082120 & -0.707476 \\
\hline Std. Sapma & 0.265802 & 0.266386 & 0.279073 & 0.231475 \\
\hline Çarpıklık & -0.508805 & -0.499014 & -0.584854 & -0.349300 \\
\hline Basıklık & 3.192254 & 4.253083 & 4.015889 & 3.113305 \\
\hline Jarque-Bera & $5.094327^{*}$ & $48.75927^{* * *}$ & $17.60183^{* * *}$ & $4.716619^{* * *}$ \\
\hline ADF & $-10.97954^{* * *}$ & $-20.47068^{* * *}$ & $-25.48879^{* * *}$ & $-16.14334^{* * *}$ \\
\hline PP & $-12.20234^{* * *}$ & $-32.31842^{* * *}$ & $-76.66389^{* * *}$ & $-21.88708^{* * *}$ \\
\hline KPSS & 0.123066 & 0.122075 & 0.127948 & 0.088862 \\
\hline$Q(30)$ & 37.115 & $62.077^{* * *}$ & $353.74^{* * *}$ & 28.696 \\
\hline$Q^{2}(30)$ & 21.613 & $71.098^{* * *}$ & $380.39^{* * *}$ & $71.098^{* * *}$ \\
\hline ARCH-LM & 0.005073 & $2.162168^{*}$ & $33.00018^{* * *}$ & $8.339516^{* * *}$ \\
\hline Gözlem Sayısı & 114 & 456 & 176 & 226 \\
\hline
\end{tabular}

Not: ${ }^{* * *}, * *,{ }^{*}$ sırasıyla $\% 1, \% 5$ ve $\% 10$ önem düzeylerinde anlamlılıkları ifade etmektedir. $\Delta$ değişkenin birinci farkının alındığını göstermektedir. 
Tanımlayıcı istatistikler genel olarak ele alındığında, tüm fiyat serilerinde ARCH etkisinin varlığı dikkat çekmektedir. Bununla birlikte, serilerde gözlem sayısının azlığına rağmen otokorelasyon etkisine de belirgin şekilde rastlanmaktadır. Durağanlık açısından değerlendirildiğinde, $\Delta \mathrm{L}$ tüm kapanış serilerinin 3 durağanlık testine göre istisnasız olarak durağan oldukları raporlanmıştır. Gözlem istatistiklerinde de görüldüğü üzere henüz gözlem sayıları sağlıklı bir şekilde analiz yapmak için yeterli olmaktan uzaktır.

\subsection{Genç Piyasalarda Etkinlik ve Volatilite Yapılarının İncelenmesi}

Uzun hafıza özelliğinin sağıklı bir şekilde modellenebilmesi için seriler, yeterli gözlem sayısına sahip olmadıklarından dolayı, 4 yeni kripto para birimi standart GARCH süreçleriyle modellenmişlerdir. Bu modellerde piyasa hacmi ile fiyat volatiliteleri arasındaki ilişki incelenmiştir.

Tablo 5: ADA, NEO, BCH ve MIOTA GARCH Modeli Tahmin Sonuçları

\begin{tabular}{lllll}
\hline \hline & NeoHacim & AdaHacim & BchHacim & lotaHacim \\
\hline \hline Katsayı & $-0.0004^{* * *}$ & $-0.003555^{* * *}$ & 0,001583 & $-0.0034^{* * *}$ \\
Anlamlılık & $(0.000)$ & $(0.0000)$ & $(0,981)$ & $(0.0000)$ \\
ARMA Süreci & $\mathrm{AR}(6) \mathrm{MA}(6)$ & $\mathrm{AR}(2)$ & $\mathrm{AR}(1) \mathrm{MA}(1)$ & $\mathrm{AR}(1) \mathrm{MA}(1)$ \\
\hline \multirow{2}{*}{ ARCH(Alpha1) } & $0,093264^{* * *}$ & - & $0.4785^{* * *}$ & $0,112175^{* * *}$ \\
& $(0.0000)$ & - & $(0.0000)$ & $(0.0000)$ \\
GARCH(Beta1) & $0,880947^{* * *}$ & $0.546074^{* *}$ & $0.4714^{* * *}$ & $0,764808^{* * *}$ \\
& $(0.0000)$ & $(0.0278)$ & $(0.0000)$ & $(0.0000)$ \\
ARCH-LM (5) & 0.8591 & 0.3932 & 0,65167 & 0,82595 \\
& $(0.5085)$ & $(0.8526)$ & $(0.6606)$ & $(0.5324)$ \\
\hline \multirow{2}{*}{ Box Pierce Q testi (50) } & 40.95 & 847837 & 45,0571 & 50,9074 \\
& $(0.3422)$ & $(0.3881)$ & $(0.5941)$ & $(0.3599)$ \\
\hline
\end{tabular}

Not: Parantez içindeki değerler standart hataları göstermektedir.***, ${ }^{* *},{ }^{*}$ sırasıyla \%1, \%5 ve \%10 önem seviyesi için anlamlılıkları ifade etmektedir.

Incelenen $\mathrm{BCH}$ hariç tüm kripto para birimlerinde işlem hacmi ve fiyat volatilitesi arasında anlamlı bir ilişki gözlemlenmiştir. Öte yandan bu para birimlerinin hiç birinde bu anlamlı ilişkinin katsayısı matematiksel olarak yüksek seviyede değildir. Bu durumun muhtemel bir nedeni, değişkenler arasındaki ilişkinin sağlıklı bir şekilde gözlemlenebilmesi için yeterli gözlem sayısının henüz oluşmamış olması olabilir.

\section{Sonuç}

Çalışma kapsamında elde edilen bulgular, kripto para birimi piyasaları için hayati öneme sahip bir problemin varlığına işaret etmektedir. Bu problem, kripto para birimlerinin teknik alt yapısında var olan, piyasa katılımcılarının teknik olarak üstün olan kripto para birimlerini eski kripto para birimlerine tercih edeceği varsayımıdır. Bu varsayım, finansın en temel ilkelerinden birisi olan risk ve getiri ilişkisi açısından piyasa dinamikleriyle çelişmektedir. Piyasaya yeni arz edilen kripto para birimleri, düzenleyici kurumların var olmadığı kripto para piyasalarında teorik olarak sonsuz riske maruz kalmaktadır. Bu durum piyasa hacmi düşük olan kripto piyasalarda uygulamalı olarak da gözlemlenmektedir. Yeni kripto para birimlerinin arz edildiği sığ piyasalarda, manipülasyon olarak yorumlanabilecek karakterde ve yoğunlukta volatilite seviyeleri söz konusudur. Öte yandan eski ve olgun kripto para birimlerinde derinleşen piyasa ile birlikte volatilite hızla azalmaktadır. Bu durum, katlandığı bir birim risk karşılığında elde edeceği getiriyi 
maksimize etmek isteyen rasyonel yatırımcı için, yeni arz edilen kripto para birimleri piyasalarının değişkenlik katsayısını aşırı yükseltmektedir. Diğer bir deyişle, kripto para birimlerine ait teknik altyapı, finansal piyasaların dinamikleriyle çelişecek şekilde tasarlanmıştır.

Ekonometrik açıdan, araştırma bulgularına göre olgun kripto para piyasalarında derinlik arttıkça volatilitede azalma söz konusudur. Bu, piyasaların zamanla daha yüksek hacme sahip olacağı varsayımı altında, giderek daha etkin hale geleceğinin bir işareti olarak yorumlanabilir. Piyasada en köklü kripto para birimleri olan Bitcoin, Litecoin, Ethereum ve Ripple istisnasız olarak uzun hafıza özelliğine sahiptir. Uzun hafıza özelliğinin varlığı, piyasanın şu anki haliyle etkin olmadığına dair ciddi bir bulgu olarak değerlendirilebilir. Ancak bu piyasaların kontrolsüz, denetimsiz ve oldukça genç piyasalar olduğunu göz önünde bulundurulduğunda bu yargıya varmak için henüz erken olacaktır. Uzun hafıza özelliklerini dikkate alarak değerlendirilen kripto para birimi modellerinin Ripple hariç hepsinde hacim arttıkça volatilitenin düştüğü sonucuna tutarlı bir şekilde ulaşılmıştır. Bu, piyasaların uzun vadede etkinliğinin artacağına işaret eden bir bulgudur. Uzun hafıza özelliği finansal zaman serilerinin ortak problemidir (Kayalıdere vd., 2012: 137). Kripto para serilerinde sıklıkla otokorelasyon problemi ile karşılaşılması, uzun hafıza özelliğinin kripto para birimleri piyasasının da karakteristik bir özelliği olması ihtimalini güçlendirmektedir.

Genç kripto para birimleri analiz edildiğinde uzun hafıza özelliğinin varlığından söz edilemezken hacim ve volatilitesi arasında anlamlı bir ilişki bulunmuştur. Fakat bu ilişki ekonomik olarak anlamlı olabilmek için oldukça zayıf bir ilişkidir. Çalışma sonuçlarına göre, sisteme uygulanan şokların piyasa etkinliği üzerindeki etkisi olumsuz yöndedir. Ayrıca, bulgular bu etkinin yapay olabileceğini ortaya koyduğundan şoklar üzerine yeni bir araştırma yapma ihtiyacı doğmaktadır.

İçten bilenlerin ticaretinin mümkün olmadığı piyasalarda da bu durumun tutarlı bir şekilde ortaya çıkıyor olması etkinsizliğin kaynağına ulaşabilmek için sıçrama analizlerine olan ihtiyacı güçlendirmektedir. Öte yandan kripto para piyasalarının ulusal rezerv para birimlerinin yerini alacak seviyede kabul görmesi için piyasa volatilitesinin minimum seviyeye inmiş olması yeterli midir? Yeni bir piyasada fiyatların sürekli artış eğiliminde olması bu piyasanın kesin olarak "Balon" olduğuna mı işaret eder? Kripto para birimleri bir gün ansızın tüm değerini kaybedip tarihin en büyük "Balon" ları arasında yerini alacak başka bir aldatmaca mıdır? Bu soruların yanıtlarına ulaşabilmek için yeni çalışmalara ihtiyaç duyulmaktadır.

Bu belirsizlik ortamı altında portföy yöneticileri tarafından, kripto para birimi piyasalarına yapılacak yatırımların, hesaplanmış risk olarak kategorize edilmesi mümkün değildir. Volatilitenin uzun vadede varlığını koruyamama ihtimali yüksek kripto para birimlerinde azalması, yatırımcılar için aldatıcı niteliktedir. Kanun koyucuların finansal okur yazarlığı düşük ve risk algısı oluşmamış yatırımcıları, mümkün olduğunca bu piyasalardan uzak tutucu politikalar izlemesi önerilmektedir. 


\section{Kaynaklar}

Baillie, Richard T; Tim Bollerslev; Hans Ole Mikkelsen (1996), "Fractionally integrated generalized autoregressive conditional heteroskedasticity", Journal of Econometrics, Vol.74 No.1: 3-30.

Balcilar, Mehmet; Elie, Bouri; Rangan Gupta; David Roubaud (2017), "Can volume predict Bitcoin returns and volatility? A quantiles-based approach", Economic Modelling, Vol.64 No.1: 74-81.

Barkoulas, John T; Christopher, F. Baum; Nickolaos Travlos (2000), "Long memory in the Greek stock market", Applied Financial Economics, Vol. 10 No. 2: 177-84.

Bollerslev, Tim; Robert, F. Engle; Daniel B Nelson (1994), “ARCH models”, Handbook of econometrics, Vol. 4 No.1: 29593038.

Bollerslev, Tim; Hans, Ole, Mikkelsen (1996), "Modeling and pricing long memory in stock market volatility", Journal of Econometrics, Vol. 73 No.1: 151-84.

Burton, John (1987), "Privatization: the thatcher case", Managerial and Decision Economics, Vol. 8 No.1: 21-29.

Caporale, Guglielmo Maria; Spagnolo, Nicola (2003), "Asset prices and output growth volatility: the effects of financial crises.", Economics Letters, Vol. 79 No. 1: 69-74.

Ceylan, Fatih;Tüzün, Osman; Ramazan, Ekinci; Hakan, Kahyaoğlu (2018), "Kripto para piyasalarında finansal balonlar (bubbles): Bitcoin ve Etherium.", 4th SCF International Conference on Economic and Social Impacts of Globalization and Future of Turkey-EU Relations: 207-215.

Cheah, Engtuck; John, Fry (2015), "Speculative bubbles in Bitcoin markets? An empirical investigation into the fundamental value of Bitcoin", Economics Letters, Vol. 130 No.1: 32-36.

Cheung, Yin-Wong; Kon, S. Lai (1993), "Finite-sample sizes of Johansen's likelihood ratio tests for cointegration", Oxford Bulletin of Economics and Statistics, Vol. 55 No.3: 313-28.

Cheung, Yin-Wong; Kon, S. Lai (1995), "A search for long memory in international stock market returns", Journal of International Money and Finance, Vol.14 No.4: 597-615.

Chu, Jeffrey; Stephen, Chan; Saralees, Nadarajah; Joerg, Osterrieder (2017), "GARCH modelling of cryptocurrencies.", Journal of Risk and Financial Management, Vol.10 No.4: 17.

Cocco, Luisanna; Giulio, Concas; Michele, Marchesi (2017), "Using an artificial financial market for studying a cryptocurrency market.", Journal of Economic Interaction and Coordination, Vol.12 No.2: 345-365.

Ding, Zhuanxin; Clive, WJ. Granger; Robert, F. Engle (1993), "A long memory property of stock market returns and a new model", Journal of Empirical Finance, Vol.1 No.1: 83-106.

Dirican, Cuneyt; Canoz, İsmail (2017), "The cointegration relationship between Bitcoin prices and major world stock indices: An analysis with ARDL model approach.", Journal of Economics, Finance and Accounting, Vo.4 No.4: 377392.

El Bahrawy, Abeer; Alessandretti, Laura; Kandler, Anne; Pastor-Satorras, Romualdo; Baronchelli, Andrea (2017), "Evolutionary dynamics of the cryptocurrency market.", Royal Society Open Science, Vol.4 No.11: 170623.

Engle, Robert, F. (1982), "Autoregressive conditional heteroscedasticity with estimates of the variance of United Kingdom inflation", Econometrica: Journal of the Econometric Society, Vol.1 No.1:987-1007.

Fama, Eugene, F. (1965a), "Portfolio analysis in a stable Paretian market", Management Science, Vol.11 No.3: 404-19.

Fama, Eugene, F. (1965b), "The behavior of stock-market prices", The journal of Business, Vol.38 No.1: 34-105.

Fama, Eugene, F. (1970), "Efficient capital markets: A review of theory and empirical work", The journal of Finance, Vol.25 No.2: 383-417.

Gandal, Neil; Halaburda, Hanna (2014), "Competition in the cryptocurrency market.", https://papers.ssrn.com/sol3/papers.cfm?abstract_id=2501640, (Erişim: 02.03.2018).

Gandal, Neil; Halaburda, Hanna (2016), "Can we predict the winner in a market with network effects? Competition in cryptocurrency market", Games, Vol. 7 No.3: 16.

Granger, Clive, WJ.; Roselyne, Joyeux (1980), "An introduction to long-memory time series models and fractional differencing", Journal of time series analysis, Vol.1 No.1: 15-29.

Hosking, Jonathan, RM. (1981), "Fractional differencing”, Biometrika, Vol.68 No.1: 165-76.

Kayalıdere, Koray; Hakan Aracı; Hüseyin Aktaş (2012), "Türev ve spot piyasalar arasındaki etkileşim: VOB üzerine bir inceleme", Muhasebe ve Finansman Dergisi, C.56 S.1: 137-54. 


\section{Eskişehir Osmangazi Üniversitesi IïBF Dergisi}

Krafft, Peter; Nicolás, Della Penna; Pentland, Alex Sandy (2018), "An experimental study of cryptocurrency market dynamics." 2018 CHI Conference on Human Factors in Computing Systems: 605.

Lahmiri, Salim (2015), "Long memory in international financial markets trends and short movements during 2008 financial crisis based on variational mode decomposition and detrended fluctuation analysis", Physica A: Statistical Mechanics and its Applications, Vol.437 No.1: 130-38.

Mensi, Walid; Shawkat, Hammoudeh; Sang, Hoon, Kang (2015), "Precious metals, cereal, oil and stock market linkages and portfolio risk management: Evidence from Saudi Arabia", Economic Modelling, Vol.51 No.1: 340-58.

Nakamoto, Satoshi (2008), "Bitcoin: A peer-to-peer electronic cash system.", http://www.blockchainstarter.eu/BTCwhitepaper.pdf, (Erişim Tarihi: 01.01.2016).

Tse, Yiu Kuen; (1998), "The conditional heteroscedasticity of the yen-dollar exchange rate", Journal of Applied Econometrics, Vol.1 No.1: 49-55.

Turgutlu, Evrim (2004), "Fisher hipotezinin tutarlılığının testi: parçalı durağanlık ve parçalı koentegrasyon analizi”, DEÜ iiBF Dergisi, C.19 S.2: 55-74. 